\title{
Muslim Public Self-Presentation: Interrogating the Liberal Public Sphere
}

\begin{abstract}
$\mathrm{n}$ this article I want to address a number of issues thrust into the open by different manifestations of Islamist politics and the intersection of religion and identity politics in Western societies. This intersection should be read in conjunction with the emergence in Muslimmajority societies of forms of political activism that ground themselves in Islamic doctrines and invoke religious traditions as frames of reference. It is necessary in reading the contentions surrounding Muslim identity politics in Western settings that we take into account factors shaping the dynamics of interaction between Western countries and Muslim societies, not least among which are the long-standing historical relations associated with the colonial experience and its aftermath.
\end{abstract}

In this paper I argue that the contentions surrounding Muslim public self-presentation in Western public spheres arise in conjunction with the historical traditions of discipline and normalization in relation to which Muslims are proving to be recalcitrant subjects. Further, the projections of Muslim subjectivities in liberal public discourses are underpinned by assumptions about subject populations rooted in colonial discourses and practices. The liberal project of government in colonial settings rested on assumptions about the colonized, in particular relating to matters of sexuality, gender, and morality. Contemporary Muslim interrogations of the liberal public sphere face off with forms of government and discipline that hark back to the relations between the colonizer and the colonized. On one hand, the dominant groups in Western societies tap into historical constructions of the Other, while Muslim minorities, among others, in the West are informed by the legacies of colonialism.

In its earlier phases Islamist politics in Muslim-majority societies was anchored within the boundaries of the nation-state and, as such, its implications for non-Muslim societies, in particular Western ones, appeared to be of secondary nature. ${ }^{1}$ The situation changed when certain kinds of Islamist activism shifted locale and targets and moved to the West. At this point, the challenge of what came to be termed radical Islam became a major preoccupation of public opinion and policy-makers alike. I want to suggest that the concern with the challenge of militant Islamism, while in some respects justified, is often collapsed with another separate, but related challenge posed by certain forms of politics that Muslims engage in. Of these forms I want to focus on Muslim public self-presentation in the liberal public sphere and the questions that this puts to liberal norms and values. But before I do that, I will make two digressions. First, I will overview some assumptions about the liberal public sphere. Second, I will highlight how these assumptions have been negotiated by Muslim-majority societies historically and in the present. Following that, I will turn to the terms in which Muslim public self-presentation in secular Western societies interrogates the liberal public sphere.

\section{Muslims and the Secular Imperative of the Liberal Public Sphere}

The debates about "Islam in Europe" and the place of Muslims in European societies are to a great extent organized against the background of assumptions about the liberal public sphere as an essential component of the Western democratic polity. Readings and assessments of Muslim public self-presentation and the signs of Islam in the public space are framed by the assumptions of the secular liberal public sphere. These readings and assessments are presented as expressions of an achieved consensus on the nature of the public sphere and public space and as an affirmation of highly valorized norms and values. However, the terms through which Muslim practices of public self-presentation are problematized in such assessments, as Nilüfer Göle $(2002,178)$ points out, inform us of the "unspoken, implicit borders and the stigmatizing exclusionary power structure of the secular public sphere."

In principle and according to conventional understandings - formalized by Habermas - the public sphere is an arena of deliberation and debate involving rational subjects. The underlying premise is that of neutrality and equality: neutrality towards identity and equality of all subjects. In some sense, subjects of the public sphere are presumed to be non-marked, equal, and universal. But as critics of this formulation point out, this neutrality is questionable (see Benhabib 1992; Fraser 1992; Warner 1992). The taken-for-granted public subject is not neutral, but male, white, middle class, and secular. Further, it is pointed out that the idea that in the public sphere impartial reason stands above 
and against differentiated moral subjects serves to sanction particular subjects and invalidate others. In other words, the normativity of the secular public sphere is accomplished by exclusion, stigmatization and repulsion of subjectivities falling outside its confines.

As argued by a number of scholars, the public sphere is not just an arena of deliberation, but also a space of identity formation through performances of subjectivities and visual displays as well as through validation and authorization (see Warner 1992; Cinar 2005). As such, an examination of the contentions surrounding certain forms of identity-formation and selfpresentation in the public sphere helps inform us of the inclusionary and exclusionary practices at work. As noted above, in the secular public sphere the dynamics of identity and difference play out in relation to the presumed neutral and unmarked subjectivities, the ones taken for granted and validated. Others who differ are stigmatized, marked, and potentially excluded.

The contemporary contentions surrounding Muslim public self-presentation in Western settings should be read in light of the historical entanglements of the colonial encounter, in particular, in relation to discourses and practices of power at the heart of colonial governmentality. Colonial regimes of discipline were instrumental in redrawing the boundaries of the public and private in colonized societies (Cooper 1992). At the same time, elites in the colonized countries acceded to the conditions of the secular public sphere in order to renegotiate their authority and leadership roles within the project of modernity (Gasper 2001). In this regard, the secularization of the public sphere was accepted as an imperative of civilization and progress by Muslim intellectuals and leaders in many Muslim-majority societies following their encounter with Western modernity. Historically for Muslims in Muslim-majority societies negotiating modernity was shaped by this secular imperative. The project of modernization integrated secularization of the public sphere, taking the form of banishing signs of religion from the public domain, effecting state control over religion, and instituting secular reason. Further, the objects of change and reform identified in the project of modernization were shaped by the sensibilities articulated in Western accounts and critiques of local traditions and practices. $^{2}$ For example, the idea of the liberation of Muslim women through education and unveiling emerged as a necessary condition of modernization that most often was modeled after the Western experience. Muslim intellectuals subscribed to the view propagated in colonial discourses about the condition of Muslim women as a reflection of the backwardness of Muslim societies (see Ahmed 1992).

If we consider the development of the secular public sphere in Turkey, Iran, and Egypt we find that the banishment of certain signs and markers, like the veil, was enacted as a form of a secularizing and modernizing rite of passage. ${ }^{3}$ As Göle argues, women in Turkey became a "sign/site" in the construction and projection of the public sphere (Göle 2002, 184). In the same vein, forced unveiling in Iran in the first half of the twentieth century, as pointed out by Minoo Moallem (2005, 69), constituted "a corporeal inscription of modern citizenship." Following a similar logic, the taking off of the veil by Huda Sha'rawi (Egypt's pioneer leader of the women's movement in the earlytwentieth century) upon her return from Europe, was one of those performative acts marking Egypt's passage or entry into the space and time of modernity. ${ }^{4}$ Imbued with the meanings invested through secular practices, the veil appeared as the sign of backwardness, a regression in the civilizing process with its associated styles of dress. The social imaginary that articulates these views and projects them into the public gaze, then, necessitates banishment and exclusion. ${ }^{5}$ Through a particular historical construction, the unveiled woman was an affirmation of the modern self. By extension, the absence of signs of Islamicity was construed as evidence of a modernizing society, indeed of a civilizing one.

\section{The Liberal Public Sphere: Disciplining Muslim Subjectivities}

The reassertion of religion in the public sphere puts into question the integration of secularism into the project of modernity in both Muslim-majority societies and in Western societies. In the former, Islamist movements have agitated for forms of politics anchored in certain constructions of religion as captured in the idea of the Islamic state and Islamic government. Here, there may appear to be an instrumentalization of religion for political ends. Along with the declared political agenda of Islamist movements, there has also been a project of Islamization that is not political in the narrow sense (i.e., it is not about state and government), but political in the broad sense as it relates to relations of power in society, rearranging gender relations, family norms, and modes of conduct in public and interaction.

This broad Islamization agenda brings back a politics of visibilization of markers of the Islamic identity. Being Muslim is asserted through dress, modes of conduct in public, selfeducation in religion, and disciplining and representing oneself according to proffered modes of the ideal or good Muslim. This has a wide set of political implications with different slants according to the context in which Islamization takes place. In Muslim-majority societies, Islamization drives manifested themselves with reference to the safeguarding of religious orthodoxy by governing public morality. Much activism in this domain has focused on the governance of gender relations, and the regulation of cultural products and intellectual expressions in terms of the rules of the licit and illicit (however constructed). So, we have had the famous episodes of seeking to ban books, films, billboards, and the like. Alongside this activism, there is a growing adoption of religious attributes and self-fashioning after the image of the ideal Muslim, again proffered by diverse authorities to different effects.

Various accounts explaining the assertion of religiosity in public are given by the subjects involved, by scholars and by agents of the state. These accounts are sometimes overlapping and often competing and contradictory. On one hand, we have subjects who claim that their self-presentation is a matter of their faith and is not about politics. This account is given in both Muslim-majority and Muslim-minority societies. We also have scholars who wish to privilege this account on the merit that it is validated within existing religious traditions. In contrast, policy-makers and some scholars have located this agency in the sphere of contestation politics and claim-making that in secular society is problematized as expressing a break away from the norms of the secular public sphere. And we have here the concerns about integration and good citizenship. In this respect, a wide range of public policies project Muslim subjectivities that are stigmatized and seen to be in need of reform and remake. Certain practices of Muslim public self-presentation and norms of interaction are problematized in public policy debates and regulations. The questions of women adopting the veil and Muslim attitudes about sexual mores have emerged as key subjects of discussion and as targets of normalization.

Illustrative of the divergent ways of framing the question of Muslim public self-presentation are the numerous episodes of hijab management in France, the UK, and other European countries. As argued by Talal Asad (2006), what emerges in such episodes reveals more about the subjectivities that the states in question wish to allow and nurture and those that they do not wish to sanction. What transpires with the visibilization of the signs of Islamicity is the assertion of corporeal, gendered, and 
spatial practices of self that are read not only as distinct from the dominant practices of secular society, but as contrary, offensive, and threatening to the ones necessitated for the performance of the secular subject-the one who, as in the French case, appears as the subject worthy of valorization and protection as the Stasi Commission on Laïcité assured (Le Monde 2003).

The performances of the Muslim self through the adoption of the veil is interpreted as a manifestation of backwardness, patriarchal domination, false consciousness, and arrested intellectual development (the Stasi Commission on Laïcité). The Commission affirmed that in the educational setting, the headscarf as a sign that has a visible religious character is perceived by many as contrary to the educational mission of providing a neutral space for critical consciousness to grow. However, far from being neutral, the terms of this intervention assert the prerogatives of the French state in forming subjects through the secular educational system (Asad 2006, 217-9). In this system, the norms promoted are posited as emancipatory in contrast to the presumed oppression associated with hijab-wearing (Stasi Commission on Laïcité), a practice interpreted as reflecting male dominance and female subservience.

State intervention, backed up by an apparent public consensus, appeals to the principles of the higher good of women, asserting that the goal is to save them from oppression. The underlying assumption here is that some individuals, in this case, Muslim immigrant women, are incapable of free autonomous action and hence cannot be depended upon to govern themselves in accordance with liberal norms. This assumption as argued by Hindess (2001) lies at the heart of liberalism as a project of government and justifies interventionist governmental measures aimed at reform of these lesser subjects. The framing of the issue in terms of oppressed Muslim women in need of emancipation is not without grounding in colonial discourses and policies (Abu Lughod 2002). Guénif-Souilamas shows the terms of the contemporary reconfiguration of earlier paternalistic colonial policies towards women. In this reconfiguration of colonial discourses and practices, the Arab boy and the beurette emerge as two organizing figures in debates on citizenship and society (Guénif-Souilamas 2002, 2003). The former is a figure of menace, while the latter is the successful subject of the state's normalizing and civilizing policies.

Images of the Other in colonial discourses and techniques of discipline that were developed in colonial practices are redeployed in the new context. The effect has been the displacing of the conditions that structure subject positions and compelling certain subjectivities while stigmatizing and denying others. Thus, the image of the violent Arab youth who is oversexed and out of control recalls the figure found in colonial narratives of the deviant Arab whose mores were explained by an aberrant religion tolerant of transgressive sexuality. Such constructions do not consider that the macho Arab youth may be a particular refiguring of a declining working class culture formed in the image of the dominant society by those immigrant workers ghettoized in the suburbs (Guénif-Souilamas 2002). This refiguring that may take the form of machismo on the part of the children of immigrant workers pushed into greater marginalization finds its grounding in a hypersexuality previously valorized in the adopted countries (Guénif-Souilamas 2002). Rather, the stigmatization of particular subjectivities articulates with an essentialization of Arabs and Muslims, confining their identities to fixed traits and attributes from which they cannot escape.

The association of Muslim identities with violence and with the negation of Republican citizenship compels the formation of new subjects seeking recognition in the public sphere. As argued by Ruth Mas (2006), the "secular Muslim" as the subject of action in recent contestations in France is a compelled sub- ject. ${ }^{6}$ The secular Muslim is formed in opposition to the identification of "Muslim" as a violent and non-integrated Other, asserting the possibility of identifying as both Muslim and secular citizen of the Republic. This can only be achieved by marking difference with the conventional classification of Muslim as believing and practicing. ${ }^{7}$ At the same time, the link between the current techniques of government and the violence of the colonial practices is acknowledged in the assertion of the compelled subjectivities. The marchers and petitioners of "secular Islam" express their rejection of the new reserves of the banlieues (Mas 2006). The petition submitted in connection with a demonstration, named Marche des indigènes underscored the continuity of colonial practices and activities in the state's treatment of populations from the former and present colonies (Mas 2006, 600).

The dynamics of direct and indirect colonial rule are at work in the management of Muslim immigrants in contemporary Western societies. In an extension of the politics of "customary law" that were an important element of "indirect rule," the governing of "post colonial" subjects requires the establishment of local authorities and the incorporation of customary laws with the proviso that they do not contradict the repugnancy laws, i.e., the laws that define the outer limits of the civilized order. ${ }^{8}$ It is these laws that new immigration directives and regulations embody. They signal to Muslims that their customary rules are permissible within the confines of norms of liberal government. In a reissue of the repugnancy laws, Western immigration ministries and directorates concerned with the management of cultural diversity put out a list of non-permissible acts-selfevident repugnant acts-that are normally associated with Muslims, namely divorce by repudiation and female circumcision. However, as the list expands, the civilized order faces its limitations, or perhaps must expose its authoritarian face.

In addition to the strategies of indirect rule being redeployed in the governing of immigrant populations, the detailed policies of reform and improvement devised in direct rule have their resonance in the disciplining policies aimed at Muslim subjects. As pointed out by Mamdani (1996), the system of indigénat, devised by the French colonial administration in Algeria, put into effect rules governing the quotidian and the mundane, punishing minor non-conformities with the civilized order. Indeed, the objective of reforming the recalcitrant subjects by teaching them to respect authority was paramount (Mamdani 1996, 126). Under direct rule, natives were required to conform to European laws and only the civilized among them were to gain European rights (Mamdani 1996, 16), while others were excluded. In order to be admitted and recognized in the public sphere, the natives had to conform to the rules of this order. To this end, colonial government concerned itself with the self-presentation of colonial subjects. In his revealing essay on the management of the natives' attire by the British colonial administration in India, Bernard Cohn (1992) shows the disciplining dimensions of the regulations on the wearing of shoes, turbans, caps, and other items of clothing. The regulations of clothing and the strategies of representation that they involved were part of the production of the civilized subject. In a similar manner, the French colonial rulers conceived of unveiling women as one of the civilizing accomplishments of colonial government. Thus conformity in public self-presentation to the rules and images put out by the colonial government was essential to gaining entry into civilized society and its public sphere. This is captured in Cecil Rhodes's assertion that "citizenship would be a privilege of the civilized" and that "equal rights [are] for all civilised men" (quoted in Mamdani 1996, 165).

With a view to disciplining the potentially recalcitrant Muslim subjects, immigration policies in a good number of European countries aim to ensure the admission of reformed and 
normalized Muslims. Towards this end, prospective Muslim applicants are examined and assessed on their attitudes on issues of sexual mores and gender interaction, and on their tolerance towards difference. These practices of governance aimed at Muslims embody techniques of normalization while also revealing the assumptions underlying the constructions of Muslims as radically different and, most likely, culturally alien. In these constructions, religion appears as the defining element of identity, relegating other factors such as gender, class, and social background to a secondary place in the constitution of Muslim subjectivities. As such the tests and examinations to which they are subjected are intended to determine the degree of their openness and acceptance of liberal norms and, by extension, the extent to which they are able to shed their religious attachments. The successful subject of these examinations and tests must be able to demonstrate certain sensibilities on gender issues and sexual mores. ${ }^{9}$

Negative sensibilities in response to Muslims have conjured up in Western imaginaries certain types of Muslims who represent a particular threat that must be dealt with. A recent incident that took place in Quebec, anecdotal as it may be, illustrates how much there is a felt need to regulate and manage Muslim public presence and practices. In January 2007, the town council of Hérouxville, a small town in a rural region of Quebec, issued a code of behavior for prospective immigrant-residents outlining "how we do things here." The gist of it is that gender mixing and unrestricted dietary provisions are the norm; covering the hair, stoning, and burning women alive are not and will not be allowed. Hérouxville's code appears as an anomaly; the town has a single immigrant family, and it is undoubtedly known by all that stoning and burning alive are prohibited by the Canadian criminal code. So, there does not seem to be a reason for Hérouxville's action. But what Hérouxville undertook is not much different from earlier Quebec government attempts to devise codes governing the expressions of Muslim subjectivities. In the early 1990s, the Quebec Ministry of Cultural Communities and Immigration issued a guiding document to prospective immigrants that was distributed through immigration offices and indicated practices illegal in Quebec. These included female circumcision and divorce by repudiation.

Beyond the question of the role of religion in public lies the challenge of society as an ongoing project or an unfinished business. While Hérouxille was signaling the fixity of its values, and later on the Quebec Premier, when he waded in on the en- suing debates, insisted that some things were not negotiable, the reality of immigration and diversity reopens old debates and demands negotiation. ${ }^{10}$

The paradox for liberal secular society and liberal political rule is that though convinced by the superiority of its values and norms and the attendant subjectivities it authorizes, it must also attend to the exigencies of an image of self that does not acknowledge the dynamics of power at play, in particular the exclusionary practices that are ultimately maintained by the privileging of secular subjectivities. Again, as Talal Asad points out the Commission on Laïcité was more about reaffirming the secular character of the French Republic than about tolerance and inclusion. Asad correctly argues that the Commission delved into the motives and emotions of the scarf-wearers in order to determine their suitability for the secular personality of the Republic. In other words, this was ultimately an exercise in sovereignty through the state's assertion of its control of signs in the public sphere and of its powers of forming and disciplining subjects.

\section{Concluding Remarks}

I want to end by suggesting that the apparent inconsistencies of liberalism are built-in inconsistencies that result from a mode of government that relies on individuals to govern themselves in a particular way that is consistent with the norms of secular subjectivities. When individuals and groups fail to govern themselves in the terms prescribed, then liberal modes of governance shift gear to illiberal practices in order to discipline the recalcitrant subjects, beckoning them to discipline themselves according to the dominant norms of liberal rule. Judged by secular liberal norms during the colonial period, colonized populations were not at the right stage of self-governance, and as such, democratic principles of rule could not be applied in governing them. It was then thought that these populations had yet to take the same steps taken by Western society on the civilization ladder, and until they did, they were to be governed through authoritarian styles of rule. Today, the recalcitrant subjectivities performed by immigrants (in this case Muslims) are within liberal societies and the desire/need to regulate them has required the expression of a degree of intolerance as in the banning of the veil, or the a priori insistence that some things are non-negotiable.

\section{Notes}

* An earlier version of this paper was presented at the conference, Diversity and National Identity in the European Union: Multicultural Challenges, at the Instituto Portuges de Relaçoes Internacionais, University Nova de Lisboa. Lisbon, March 22-23, 2007, Lisbon. This revised version benefited from presentations by Nacira Guénif-Souilamas and Schirin Amir-Moazami at the workshop, Conceptions of Islam, University of Bergen, August 27-31 2007, Bergen.

1. We should also recall that Islamist political forces were treated by Western power, in particular the U.S., as instruments of combat against other adversaries, mainly the Soviet Union at the global level and Arab nationalism at the regional level.

2. The Western gaze on practices of child-rearing, policies on poverty, the position of women in society, and much else informed diverse projects of reform spearheaded by indigenous elites. On Egyptian reform projects in the area of poverty for example see Ener 2003, on Indian elites' critiques of traditional practices in marriage see Panikkar 1995.

3. The discussion in this paragraph draws on Ismail 2007.

4. Later in the twentieth century, forced veiling in Iran punctuated another moment of state intervention in the perpetuation of particular forms of femininity (Moallem 2005, 70). In contrast, in Turkey and Egypt, the propa-

gation of veiling and the various modalities of its adoption serve to remap old and new subjectivities in the public sphere.

5. Such was the case with the Turkish Parliamentarian who, in 1999, was run out of Parliament before she could give her oath of allegiance because she wore a veil on the day of her swearing-in ceremony (Göle 2002).

6. Mas delineated a number of groups and activities as constituting secular Islam in France. The groups include the Mouvement des musulmans laïques de France, while activities centered in petitions such as the l'appel de mai and Le Manifeste des libertés-Être de culture musulmane et contre la misogyny, and l'appel des indigènes.

7. A similar positioning is assumed in the formulation of the movement "ni pute ni soumise" (neither whore nor submissive). For a critical reading of this positioning see Guénif-Souilamas 2003.

8. I am drawing here on Mamdani's articulation of the notions of direct and indirect rule and his insightful analysis of the integration of customary law into systems of indirect rule. New forms of indirect rule in the contemporary context include efforts by Western states to identify and in many instances to create institutions of "native" rule. In this vein, the French state assiduously went about cultivating local leaders and encouraging the formation of a national organization representative of Muslims. 
These efforts culminated in the creation of the Council of Muslims in France. See Fernando 2005.

9. In Germany, in what came to be known as the "Muslim test" administered by the state of Baden-Württemberg, Muslim applicants for German citizenship are quizzed on their views on homosexual relations, claims about the role of Jews in the world, and girls taking part in school sports activities. One question inquires into whether the applicant would approve of his/ her son having a homosexual relationship. In the Netherlands, prospective

\section{References}

Abu Lughod, Lila. 2002. "Do Muslim Women Really Need Saving? Anthropological Reflections on Cultural Relativism and Its Others." American Anthropologist 104 (3): 78-790.

Ahmed, Leila. 1992. Women and Gender in Islam. New Haven: Yale University Press.

Asad, Talal. 2006. "Responses." In Powers of the Secular Modern: Talal Asad and His Interlocutors, ed. David Scott and Charles Hirschkind. Stanford University Press, 206-41.

Benhabib, Seyla. 1992. "Models of Public Space: Hannah Arendt, the Liberal Tradition, and Jürgen Habermas." Habermas and the Public Sphere, ed. Craig Calhoun. Cambridge, MA: The MIT Press.

Çinar, Alev. 2005. Modernity, Islam and Secularism in Turkey: Bodies, Places and Time. Minneapolis: University of Minnesota Press.

Cohn, Bernard. 1992. Colonialism and Its forms of Knowledge: The British in India. New Jersey: Princeton University Press.

Cooper, Fredrick. 1992. "Colonizing Time: Work Rhythms and Labour Conflict in Colonial Mombasa." In Colonialism and Culture, ed. Nicholas Dirks. Ann Arbour: University of Michigan Press, 209-45.

Ener, Mine. 2003. Managing Egypt's Poor and the Politics of Benevolence 1800-1952. New York: Princeton University Press.

Fernando, Mayanthi. 2005. “The Republic's Second Religion: Recognizing Islam in France." Middle East Report 235 (Summer).

Fraser, Nancy. 1992. "Rethinking the Public Sphere: A Contribution to the Critique of Actually Existing Democracy." Habermas and the Public Sphere, ed. Craig Calhoun. Cambridge, MA: The MIT Press.

Gasper, Michael. 2001. "Abdallah al-Nadim, Islamic Reform, and 'Ignorant' Peasants: State-Building in Egypt?" In Muslim Traditions and Modern Techniques of Power, ed. Armando Salvatore. New Brunswick: Transaction Publishers, 75-92. immigrants are shown a video-film entitled To the Netherlands intended to expose them to the host culture, with scenes of a topless woman sunbathing and of two men kissing in a meadow.

10. In response to the debates on cultural accommodation and the controversy caused by the Hérouxville affair, the Quebec Premier established the Consultation Commission on Accommodation Practices Related to Cultural Differences, and appointed communitarian thinker Charles Taylor and historian Gérard Bouchard as co-chairs.
Göle, Nilüfer. 2002. "Islam in Public: New Visibilities and New Imaginaries." Public Culture 14 (1): 173-90.

Guénif-Souilamas, Nacira. 2003. "Ni pute, ni soumise ou très pute, très voilé? Les inévitables contradictions d'un féminsime sous influence." Cosmopolitiques 4: 53-65.

. 2002. "L'enfermement viriliste: des garçons arabes plus vrais que nature." Cosmpolitiques 2: 47-59.

Hindess, Barry. 2001. "The Liberal Government of Unfreedom.” Alternatives 26 (2): 96-111.

Ismail, Salwa. 2007. "Islamism, Re-Islamisation and the Fashioning of Muslim Selves: Refiguring the Public Sphere." Muslim World Journal of Human Rights 4 (1). www.bepress.com/mwjhr/vol4/iss1/art3.

Le Monde. 2003. "Le Rapport de La Commision Stasi sur la Laïcité." December 13.

Mamdani, Mahmood. 1996. Citizen and Subject: Contemporary Africa and the Legacy of Late Colonialism. New Jersey: Princeton University Press.

Mas, Ruth. 2006. "Compelling the Muslim Subject: Memory as PostColonial Violence and the Public Performativity of 'Secular and Cultural Islam." The Muslim World 96 (October): 585-616.

Moallem, Minoo. 2005. Between Warrior Brother and Veiled Sister: Islamic Fundamentalism and the Politics of Patriarchy in Iran. Berkeley: University of California Press.

Panikkar, K N. 1995. Culture, Ideology, Hegemony: Intellectuals and Social Consciousness in India. London: Anthem Press.

Warner, Michael. 1992. "The Mass Public and the Mass Subject." In Habermas and the Public Sphere, ed. Graig Calhoun. Cambridge, MA: The MIT Press, 377-401. 